\title{
Monoclonal antibody against a gill Rickettsiales- like organism of Pecten maximus (Bivalvia): application to indirect immunofluorescence diagnosis
}

\author{
G. Le Gall ${ }^{1}$, C. Mourton ${ }^{2}$, V. Boulo ${ }^{1}$, F. Paolucci ${ }^{3}$, B. Pau $^{2}$, E. Mialhe ${ }^{1}$ \\ ${ }^{1}$ IFREMER, LABEIM, U.R. de Pathologie, Immunologie et Biologie moléculaire, BP 133, F-17390 La Tremblade, France \\ ${ }^{2}$ Faculté de Pharmacie, Avenue Charles Flahaut, F-34060 Montpellier cedex, France \\ ${ }^{3}$ Sanofi Recherche, Rue du Professeur Blayac, F-34082 Montpellier, France
}

\begin{abstract}
Using hybridoma technology, monoclonal antibodies (MABs) were prepared against a Rickettsiales-like organism (RLO) from the gills of the Saint-Jacques scallop Pecten maximus. The 5D7 $\mathrm{MAB}$ was then selected as a specific reagent suitable for an indirect immunofluorescence assay (IIFA) and evaluated for RLO diagnosis on P. maximus gill smears. Monoclonal antibody 5D7 showed no crossreactivity with an RLO associated with a related pectinid species Chlamys opercularis.
\end{abstract}

\section{INTRODUCTION}

In pectinid molluscs, several Rickettsiales-like organisms (RLO) were observed in gill tissues and assumed to be involved in mortalities (Gulka et al. 1983). The most recent case concerned the SaintJacques scallop Pecten maximus from Saint-Brieuc Bay (North Brittany) in France, where mass mortalities have been reported at the end of each winter for 3 yr (Le Gall et al. 1988a, 1991). All specimens examined were infected. In other French scallop production areas prevalences have been variable, apparently dependent on scallop transfers and natural progression of the infection along the Atlantic and English Channel coasts (Le Gall et al. 1991). No infection has been found in Mediterranean sea scallop populations. A related gill RLO was found associated with a different pectinid, Chlamys opercularis, but was distinguishable from $P$. maximus RLO on the basis of morphology, cell localization in the gill and lack of reactivity with $P$. maximus RLO polyclonal antibodies (Le Gall et al. 1988b).

All previous epizootiological investigations examined histological sections of gills. In cases of low prevalences many samples must be taken and several histological sections must be prepared from different. regions of the gills. Thus, sample preparation and subsequent microscope examinations are tedious and time-consuming. Moreover, histological examination is not capable of distinguishing RLOs associated with related pectinids and determining alternate hosts.

A simplified diagnostic method, largely used for protozoan parasites, consists of examining stained gill smears, which are easily and quickly prepared. However, the majority of the procaryote colonies are disrupted by smearing and it is difficult, especially for low infections, to accurately distinguish RLO cells from other procaryotes. It would be useful if a quantitative diagnostic technique was available to survey the development of infections. Immunological diagnostic methods like immunofluorescence (Boulo et al. 1989) and immunoenzymatic assays (Rogier et al. 1991) would be particularly suitable and would justify the preparation of specific antibodies against RLO.

A protocol has been recently established for the isolation and purification of RLO directly from Pecten maximus gills permitting the subsequent preparation of polyclonal antibodies (Le Gall \& Mialhe 1992). However, polyclonal antibodies often give rise to difficult problems in the development of quantitative and reproducible immunodiagnostic methods because of a heterogeneity of antigen-specific immunoglobulins, a low titer of these specific antibodies and variability between serum batches (Mialhe et al. 1988). These difficulties are often resolved by development of mono- 
clonal antibodies which can be prepared using hybridoma technology (Köhler \& Milstein 1975).

Monoclonal antibodies have been obtained for several vertebrate Rickettsia and Coxiella species (Williams et al. 1984, Anacker et al. 1985) and used in indirect immunofluorescent assays (IIFA) either for diagnostic or taxonomic purposes (Yamashita et al. 1988, Vitale et al. 1989, Uchiyama et al. 1990).

In this paper, we describe a protocol for lymphocyte hybridization to prepare monoclonal antibodies against Pecten maximus RLO. A monoclonal antibody-based IIFA was developed for the diagnosis of RLO in epizootiological studies.

\section{MATERIALS AND METHODS}

Experimental scallops. 3- to 5-yr-old Saint-Jacques scallops Pecten maximus were dredged from several areas along the Atlantic and English Channel coasts: Seine Bay, St-Brieuc Bay, Brest Rade, Ouessant Island and Concarneau Bay. 1-yr-old scallops were collected from St-Brieuc Bay where they had been grown from hatchery spat, cultivated in an RLO-free area (Mediterranean) for 6 mo and then for 4 mo in an infected area (St-Brieuc Bay). Healthy scallops were obtained from Norway (Stein Mortensen, Marine Institute of Bergen). Queen scallops Chlamys opercularis were also dredged from St-Brieuc Bay.

Purification of RLO. Rickettsiales-like organisms (RLO) were purified according to the protocol of Le Gall \& Mialhe (1992). Briefly, 10 gills of parasitized Pecten maximus were dissected and homogenized with an ultra-turrax. The homogenates were then sieved through nylon tissues to remove large cellular fragments. Several differential centrifugations on discontinuous sucrose gradients were performed for progressive concentration of microorganisms. Purification was achieved with an isopycnic centrifugation on a renographin (Scherring laboratory) discontinuous density gradient.

Immunization protocol. Three mice (Balb/C) were immunized by initial intraperitoneal $(500 \mu l)$ and intravenous $(100 \mu \mathrm{l})$ injections of purified parasites suspended in physiological solution (approximately $10^{8}$ parasites $\mathrm{ml}^{-1}$ ). Two subsequent intraperitoneal injections were made at weekly intervals. The mouse with the highest serum titer received an intraperitoneal injection of $150 \mu \mathrm{l}$ of purified RLO. The final dose was administered $3 \mathrm{~d}$ before fusion under conditions designed to prevent anaphylactic shock.

Lymphocyte hybridization protocol. The myeloma cell line P3-X63-Ag8-653 was cultured in RPMI 1640 medium (Gibco) containing $10 \%$ heat-inactivated fetal calf serum (FCS), 1 mM glutamine and antibiotics.
Spleen cells were fused with the myeloma line by a method adapted from French et al. (1986) and detailed in Rogier et al. (1991). Splenocytes $\left(15 \times 10^{7}\right)$ and myeloma cells $\left(3 \times 10^{7}\right)$ were mixed and hybridized by using polyethylene glycol 1540 (Riedel de Haën AG, Germany). After fusion, the cells were distributed into microculture plates at the rate of $10^{5}$ cells well ${ }^{-1}$ in medium containing $15 \%$ FCS and hypoxanthine $\left(10^{-4}\right.$ $\mathrm{M})$, aminopterin $\left(4 \times 10^{-7} \mathrm{M}\right)$, and thymidine $(1.6 \times$ $\left.10{ }^{5} \mathrm{M}\right)($ HAT). Four days after lymphocyte hybridization, $100 \mu$ of culture supernatant in each well was replaced with fresh normal medium.

Hybridoma screening procedures. The hybridoma culture supernatants were tested using an indirect enzyme linked immunosorbent assay (ELISA) to estimate their immunological activity against RLO. For this purpose, the microtiter plates (Millititer type GV, Millipore) were hydrated with $200 \mu$ well $^{-1}$ of distilled water and then the RLO were seeded at approximately $10^{6}$ procaryotes well ${ }^{-1}$ diluted in Tris $(10 \mathrm{mM}) \mathrm{NaCl}(90 \mathrm{mM})$ buffer. The procaryote cells were then concentrated by vacuum filtration and adsorbed at $37{ }^{\circ} \mathrm{C}$ on the porous Durapore membrane $(0.22 \mu \mathrm{m})$ which constituted the bottom of the wells. When the plates were dried, saturation buffer (Tris, $10 \mathrm{mM}$; NaCl, $90 \mathrm{mM}$; Tween 20,0.1\%; $\mathrm{BSA}, 1 \% ; \mathrm{BGG}, 1 \%$ ) was introduced into each well $(200 \mu \mathrm{l})$. After incubation $\left(37^{\circ} \mathrm{C}, 1 \mathrm{~h}\right)$ the solution was filtered and the hybridoma supernatants $(50 \mu \mathrm{l})$ were deposed. Microplates were incubated again froom temperature, $1 \mathrm{~h}$ ) and then washed $(\mathrm{NaCl}, 150 \mathrm{mM}$; Tween 20,0.5\%) 5 times by flicking and 2 times by aspirating. A goat anti-mouse IgG (Biosys), labelled with alkaline phosphatase in $0.1 \%$ dilution buffer, was added and incubated $\left(1 \mathrm{~h}, 37^{\circ} \mathrm{C}\right)$. Microplates were washed again and then $200 \mu \mathrm{l}$ of enzyme substrate was added and incubated $\left(35 \mathrm{~min}, 37^{\circ} \mathrm{C}\right)$. From each well, 100 ,ll was transferred into wells of polystyrene microplate for absorbance measuring at $405 \mathrm{~nm}$.

Cloning procedure. The selected hybridomas were cloned using the limiting dilution method. The supernatants were then assayed according to the previously described hybridoma screening method (indirect ELISA).

Production and purification of monoclonal antibodies. The cloned selected hybridomas ( 3 to $5 \times 10^{6}$ cells) were injected intraperitoneally into Balb/C mice which had been injected $15 \mathrm{~d}$ before with $500 \mu \mathrm{l}$ of pristane. The ascitic fluids, which were collected 10 to $15 \mathrm{~d}$ after injection of the cells, were clarified by centrifugation and the monoclonal antibody classes were determined by indirect ELISA performed according to the screening protocol. The $\operatorname{IgG}$ and $\operatorname{IgM}$ were purified respectively by affinity chromatography with proteinA-Sepharose (Pharmacia) and gel filtration chromatography. 
Indirect immunofluorescence assay. Gill smears were prepared from small pieces of tissue which had previously been dried on blotting paper. The smears were then air-dried and fixed by immersion in acetone (10 min). They were either used immediately or kept at $-20{ }^{\circ} \mathrm{C}$. The slides were overlaid with monoclonal antibody solution, specific or control, at a final concentration of $5 \mu \mathrm{g} \mathrm{ml} \mathrm{ml}^{-1}$ in phosphate buffer (Diagnostic Pasteur). After 30 min incubation at ambient temperature in a moist chamber, the slides were washed with the same buffer and then overlaid with fluorescein isothiocyanate, and conjugated goat anti-mouse immunoglobulin antiserum (Diagnostic Pasteur), and diluted in the same buffer containing $0.01 \%$ Evans blue. The slides were again incubated as described and washed with buffer before mounting using glycerinbuffer fluid (Diagnostic Pasteur). The slides were examined for bright green fluorescent cells that were morphologically consistent with RLO.

RLO detection by light microscopy. Gill sections were prepared from tissues fixed in Carson's fixative and then processed and embedded in paraffin; $3 \mu \mathrm{m}$ sections were stained with hematoxylin and eosin. Gill smears were prepared as previously described and then air-dried, fixed and stained with Haemacolor kit (Merck).

\section{RESULTS}

Immunization of mice. Following the 3 immunizations, the serum from each mouse was evaluated by the hybridoma screening ELISA method. The mouse which had the highest serum titer at $1 / 100$ dilution was selected for the fusion.

Hybridoma screening. After $20 \mathrm{~d}$ culture, $17 \%$ of wells contained hybridomas. On the basis of preliminary ELISA results, 22 hybridomas were selected. Two further screenings were performed and 9 hybridomas were kept which had the highest reactivity against purified RLO. All these hybridomas were subsequently cloned.

Specificity of purified monoclonal antibodies. The immunological specificities of the selected hybridomas were investigated using IIFA. For the 5D7 monoclonal antibody (5D7 MAB), which is an IgM, an intense fluorescent pattern was found only on the RLO, whose large size and globular form were distinct (Fig. 1). There was no fluorescence with any of the control MABs. For all other cloned monoclonal antibodies, a discrete fluorescent pattern was observed without an easily recognized RLO form. All subsequent IIF assays were thus performed with $5 \mathrm{D} 7 \mathrm{MAB}$ which was regularly used at a final concentration of $5 \mu \mathrm{g} \mathrm{ml}^{-1}$.

Reactivity of 5D7 MAB against RLO of scallops Pecten maximus from different geographic origins. The reactivity of 5D7 MAB was investigated against RLO associated with Saint-Jacques scallops from different French geographic origins where infections were reported: Seine Bay, St-Brieuc Bay, Brest Rade, Ouessant Island, and Concarneau Bay. Positive results were obtained regardless of RLO origin, showing the suitability of this MAB as a diagnostic reagent for epizootiological studies. Moreover, Saint-Jacques scallops from Norway were confirmed to be RLO-free using both IIFA and stained section examinations.
Fig. 1. Pecten maximus. Photomicrographs showing staining pattern of 5D7 monoclonal antibody against Rickettsiales-like microorganisms (RLO) of the Saint-Jacques scallop as revealed by indirect immunofluorescence assay. (a) Scattered RLO by the smear, $\times 1300$. (b) A small RLO colony, $\times 2300$
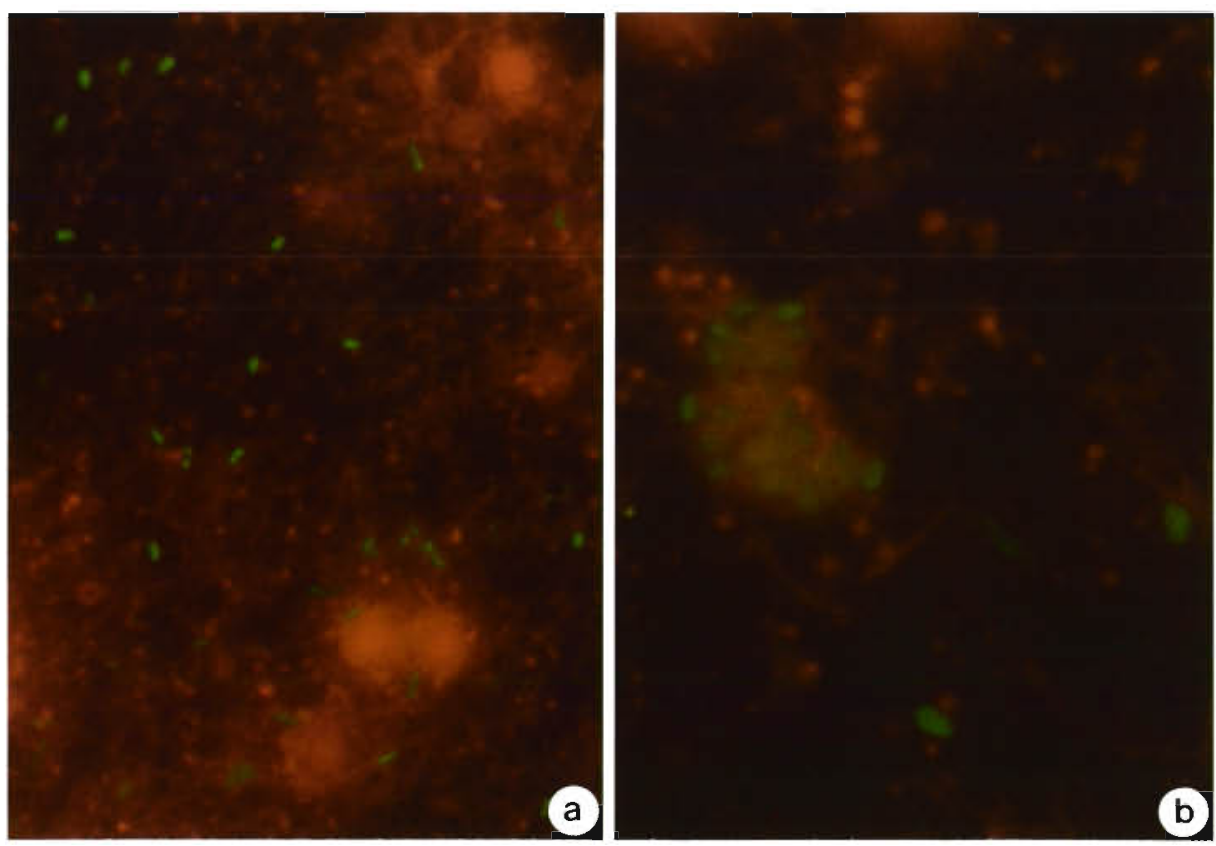
Reactivity of 5D7 MAB against RLO of Chlamys opercularis. The reactivity of 5D7 MAB against RLO associated with the queen scallop $C$. opercularis was negative using IIFA.

Comparative RLO diagnosis by IIFA and stained smears or sections. Comparisons between RLO diagnostic techniques were undertaken with 1 -yr-old scallops. Light microscope examination of stained smears of 37 scallops did not accurately identify RLO. FOr stained sections, infections were detected at low levels in 7 scallops with only one or a few colonies observed in each case, sometimes after examination of several sections. Five of these 7 scallops clearly showed RLO cells in gill smears using the IIF assay

\section{DISCUSSION}

The study of Rickettsiales-like organisms in molluscs has been essentially limited to morphological and ultrastructural data (Laukner 1983, Elston \& Peacock 1984). Reasons for studying these microorganisms include the evolution of the association between molluscs and intracellular procaryotes and the diversity of relationships that can be either symbiotic (Le Pennec et al. 1988) or pathogenic (Comps \& Raimbaud 1978, Gulka et al. 1983).

In this study, vertebrate methodologies were applied to molluscan RLO. Initially, a purification protocol was established using infected tissues (Le Gall \& Mialhe 1992) since no in vitro culture system was available for molluscan RLO. Using purified RLO suspensions, immunological techniques based on $\mathrm{MAB}$ were developed for studying the epizootiology of the infection (Anacker et al. 1987, Yamashita et al. 1988, Vitale et al. 1989, Uchiyama et al. 1990).

The preparation of monoclonal antibodies against Pecten maximus RLO is the first MAB used for RLO associated specifically with invertebrates (Weiss \& Dasch 1981, Weiss et al. 1984). The reactivity of 5D7 MAB with all geographic isolates of $P$. maximus RLO makes it suitable as a reagent for further epizootiological studies. The characteristic immunofluorescent pattern of the 5D7 MAB permitted sure and direct identification of RLO cells eliminating the possibility of false positives for IIFA. This was confirmed by a study with RLO-free scallops from Norway.

The diagnosis of RLO from Pecten maximus using 5D7 MAB-based IIFA and histological sections was compared in a large scale epizootiological survey of $P$. maximus rickettsiosis. The purpose of the study was to determine whether MAB techniques could avoid the time-consuming preparation of histological sections. There was a good correlation of results detected on stained sections and fluorescent smears, even when samples had low levels of infection. The major difficulty in the comparison of the sensitivity of each method was the absence of a reference method with $100 \%$ sensitivity. There was a discrepancy in diagnosis of the level of infection by the different methods for 2 scallops which had extremely light infections. This suggested strongly that it was not a problem of sensitivity of detection, but rather the random presence of RLO in the section of examined sample.

The lack of reactivity of 5D7 MAB with RLO associated with Chlamys opercularis confirmed results previously obtained with polyclonal antibodies (Le Gall et al 1988b) and led to the conclusion that this species is not an alternate host of $P$. maximus RLO.

This study revealed that IIF testing with MAB permits the quick and easy detection of RLO because it was possible to observe smears at a low magnification. Because the availability of this specific reagent is not limited, the IIF diagnostic method will be very useful for routine epizootiological studies and can help to elucidate the impact of RLO on Saint-Jacques scallop populations. Moreover, the hybridoma screening ELISA protocol could constitute the basis for developing quantitative 'sandwich' immunoenzymatic test, as recently developed for Bonamia ostreae, an intrahemocytic parasite of the flat oyster Ostrea edulis (Rogier et al. 1991).

Acknowledgements. The authors are grateful to Christophe Halary and Yvon Royer for their contribution in the development of this work.

\section{LITERATURE CITED}

Anacker, R. L., List, R. H., Mann, R. E., Hayes, S. F., Thomas, L. A. (1985). Characterization of monoclonal antibodies protecting mice against Rickettsia rickettsii. J. infect. Dis. 151: 1052-1060

Anacker, R. L., Mann, R. E., Gonzales, C. (1987). Reactivity of monoclonal antibodies to Rickettsia rickettsii with Spotted Fever and Typhus group rickettsiae. J. clin. Microbiol. 25 $167-171$

Boulo, V., Mialhe, E., Rogier, H., Paolucci, F., Grizel, H. (1989) Immunodiagnosis of Bonamia ostreae (Ascetospora) infection of Ostrea edulis L. and subcellular identification of epitopes by monoclonal antibodies. J. Fish Dis. 12: 257-262

Comps, M., Raimbaud, R. (1978). Infection rickettsienne de la glande digestive de Donax trunculus L. Sci. Pêche 281 $11-12$

Elston, R. A., Peacock, M. G. (1984). A Rickettsiales-like infection in the Pacific razor clam Siliqua patula. J. Invertebr. Pathol. 44: 84-96

French, D., Fischberg, E., Buhl, S., Scharff, M. D. (1986). The production of more useful monoclonal antibodies. I. Modifications of the basic technology. Immunol. Today 11: $344-346$

Gulka, G., Chang, P. W., Marti, K. A. (1983). Procaryotic infection associated with a mass mortality of the sea scallop Placopecten magellanicus. J. Fish. Dis. 6: 355-364 
Köhler, G., Milstein, C. (1975). Continuous cultures of fused cells secreting antibody of predefined specificity. Nature, Lond. 256: 495-497

Lauckner, G. (1983). Diseases of Mollusca: Bivalvia. In: Kinne, O. (ed.) Diseases of marine animals, Vol. 2. Biologische Anstalt Helgoland, Hamburg, p. 477-961

Le Gall, G., Chagot, D., Mialhe, E., Grizel, H. (1988a). Branchial rickettsial-like infection associated with a mass mortality of sea scallop Pecten maximus. Dis. aquat. Org. 4: $229-232$

Le Gall, G., Chagot, D., Mialhe, E., Grizel, H. (1988b). Mise en évidence d'une infection rickettsienne chez Chlamys opercularis (Pectinidae) et comparaison avec la rickettsie de l'espèce sympatrique Pecten maximus. 3rd int. Colloq. mar. Aquacult., p. 15-16

Le Gall, G., Mialhe, E. (1992). Purification of Rickettsiales-like organisms associated with Pecten maximus (Mollusca: Bivalvia): serological and biochemical characterization. Dis. aquat. Org. 12: 215-220

Le Gall, G., Mialhe, E., Chagot, D., Grizel, H. (1991). Epizootiological study of rickettsiosis of the Saint Jacques scallop Pecten maximus. Dis. aquat. Org. 10: 139-145

Le Pennec, M., Diouris, M., Herry, A. (1988). Endocytosis and lysis of bacteria in gill epithelium of Bathymodiolus thermophilus, Thyasira flexuosa and Lucinella divaricata (Bivalves, Molluscs). J. Shellfish Res. 7: 483-489

Mialhe, E., Boulo, V., Grizel, H., Rogier, H., Paolucci, F. (1988), Monoclonal antibodies: a tool for molluscan pathology. In Fisher, W S. (ed.) Disease process in marine bivalve molluscs. American Fisheries Soc. Special Publication 18, p. $304-310$

Rogier, H., Hervio, D., Boulo, V., Clavies, C., Harvaud, E.,

Responsible Subject Editor: A. K. Sparks, Seattle,

Washington, USA
Bachère, E., Mialhe, E., Grizel, H., Pau, B., Paolucci, F (1991). Monoclonal antibodies against Bonamia ostreae (Protozoa: Ascetospora), an intrahaemocytic parasite of flat oyster Ostrea edulis (Mollusca: Bivalvia). Dis. aquat. Org. 11. $135-142$

Uchiyama, T., Uchida, T., Walker, D. H. (1990). Speciesspecific monoclonal antibodies to Rickettsia japonica, a newly identified spotted fever group Rickettsia. J. clin. Microbiol., 28: 1177-1180

Vitale, G., Di Stefano, R., Damiani, G., Mansueto, S. (1989). Characterization of Sicilian strains of spotted fever group Rickettsiae by using monoclonal antibodies. J. clin. Microbiol. 27: 1081-1085

Weiss, E., Dasch, G. A., (1981). The family Rickettsiaceae pathogens of domestic animals and invertebrates; nonpathogenic arthropod symbiotes. In: Starr, M. P., Stolp, H., Trüper, H. G., Balows, A., Schlegel, H. G. (eds.) The procaryotes. A handbook on habitats, isolation, and identification of bacteria, Vol. 2. Springer-Verlag, p. 2161-2171

Weiss, E., Dasch, G., Chang, P. (1984). Wolbachieae. In: Krieg, N. R., Holt, J. G. (eds.) Bergey's manual of systematic bacteriology, Vol. 1, Williams \& Wilkins, p. 711-713

Williams, J. C., Johnston, M. R., Peacock, M. G., Thomas, L. A., Stewart, S., Portis, J. L. (1984). Monoclonal antibodies distinguish phase variants of Coxiella burnetii. Infect. Immunity 43: 421-428

Yamashita, T., Kasuya, S., Noda, S., Nagano, I., Ohtsuka, S. Ohtomo, H. (1988). Newly isolated strains of Rickettsia tsutsugamushi in Japan identified by using monoclonal antibodies to Karp, Gilliam and Kato strains. J. clin. Microbiol. 26: 1859-1860

Manuscript first received: June 10, 1991

Revised version accepted: August 17, 1992 